\title{
The Effect of ISO 9001 Quality Management System on Education Institutions (A Case Study of Ronaki Duhok Education Company in Iraq)
}

\author{
Bünyamin Celik (Correspondence author) \\ Dept. of Department of Languages, Ishik University, Erbil, Iraq \\ 100 mt. Street, near Filkey Baz, across Qazi Muhammad, 44001, Erbil, KRG/Iraq \\ Tel: 964-750-835-7525 E-mail: bunyamin.celik@ishik.edu.iq \\ Ömer Hakan Ölçer \\ Esse Certification, Duhok, KRG/Iraq \\ Tel: 964-772-618-3024Ｅ-mail: 1319hakan@gmail.com
}

Received: September 3, 2018 Accepted: October 20, 2018 Published: October 25, 2018

doi:10.5296/ijmis.v3i1.13596

URL: http://dx.doi.org/10.5296/ijmis.v3i1.13596

\begin{abstract}
In this study, the ISO Quality Management System and the benefits of the standards of this system to the education sector are exemplified through two high schools. These standards are used in the first high school in the article which examines the benefits of ISO 9001 applications to educational institutions, but not in the other. The general purpose of the study is to explain the benefits and effects of the ISO 9001: 2015 Quality Management System standards to all ISO certified training institutions in the world. In the article, a comparative study has been carried out over 2 different high schools affiliated to the Ronaki Duhok Education Company and the compliance of the standards and the benefits are provided to the readers. According to the results of the analysis, it has been revealed with examples that ISO 9001: 2015 contributes to education institutions in many positive ways.
\end{abstract}

Keywords: ISO 9001 standards, Quality standards, Quality objectives, Quality in education 


\section{Ml Macrothink Institute}

\section{Introduction}

Today, educational institutions are aiming to obtain ISO 9001 quality management system certification. Because this document provides various advantages for institutions in the education sector. It is essential to make a special effort to obtain an ISO 9001 quality certificate. The ISO 9001 standard is the basis for quality management systems, which have an important place in all sectors. The ISO 9001 Standard ensures that many institutions and organizations, especially educational institutions, are more comfortable in terms of management. For this reason, it is suggested to be absolutely used and integrated into the system. In this article, we will examine two high schools within the same education institution that use and do not use ISO 9001 quality management system certification and about the benefits of these standards to educational institutions. Besides, we will touch upon what advantages educational institutions can gain from obtaining this document. In doing so, we will use the comparison method.

\subsection{What is ISO?}

ISO is an abbreviation of International Standardization Organization as a basic concept. It is originally the "International Organization for Standardization". If we mention the ISO document in general, we can explain that it is a document proving the specific quality standard of various businesses operating in different service sectors. ISO standards are criterion that are set by agreeing upon the quality standard and the preparation according to the very high standards on behalf of the sectors that are serving the educational, industrial, commercial and industrial sectors in the world.

For educational institutions; concepts such as quality, efficiency, performance and competence are at the forefront of essential rules. For this reason, these concepts are leading to the development of many models such as the usage of ISO standards. Today, competition among educational institutions is very high. Therefore, every institution should work hard to be able to stand out amongst others in the competition. When it is considered in that manner, works carried out to obtain ISO 9001 standard document improves quality understanding in educational institutions. On the other hand, it is becoming compulsory to use ISO standards in order to eliminate the managerial troubles which are emerging day by day in growing institutions.

As we have already mentioned and published in our article entitled "What is the contribution of the ISO 9001 quality management system to educational institutions?" ISO standards provide the following benefits to an educational institution:

- Significantly increases profit and productivity rates

- Increases market share

- To initiate an effective management in the educational institution

- Thanks to these standards, the organization obtain an order so that employees are happy 


\section{Macrothink}

- It reduces the expenses of the institution.

- Increases the internal and external communication

- Activities are better monitored and controlled

- Increases customer and employee satisfaction

- To raise students with wide vision and who know the world

In the educational institutions applying ISO standards, the opportunity to increase their productivity through applications such as determination of duties, responsibilities and authorities, internal auditing of the institution, oversight of works, planning and improvement of training and studies are attained.

With ISO standards, Quality Management System Principles are also prepared. Through these principles, the following positive steps take place in an educational institution:

- To focus on the customer, i.e. student

- To create an Organizational Chart to bring leadership to the forefront

- To ensure that employees participate more effectively in business life

- To improve Process Approach

- To provide experience transfer

- To identify goals better

- Try to get better by constantly improving

- To have more realistic approaches in decision making

- To establish stronger trust-oriented relations with the state's official institutions

In our previous work, we also talked about the contributions of the ISO 9001 quality management system through the example of Ronaki Duhok Education Company. Duhok Boys 'College, which we will review in this study, has applied ISO standards and Duhok Girls' College has not. For this reason, we will try to tell you how important the ISO document is by comparing these 2 education institutions with actual examples. The necessary permissions for the two institutions used in this study were obtained from Ronaki Duhok Educational Institutions that they are affiliated to.

\section{Experimental Details}

\subsection{Methodology}

In this research that we have done to discover the contribution of ISO standards to educational institutions, we have dealt with two different high schools within the Ronaki Duhok Educational Institutions: Duhok Boys 'College and Duhok Girls' College. While Duhok Boys 'College applies ISO standards, these standards are not applied at Duhok Girls' College. This led us to reach the materials that allow to make comparisons. 
In our work we will address the applied standards step by step and explain by comparing two different high school examples. We will use data from July 1, 2017 to July 1, 2018 for this. (See Appendix C-1)

\subsection{Applications}

\subsubsection{Supervision of the Academic Calendar}

The academic calendar supervision is basically a form for the purpose of creating an academic calendar and then monitoring it in terms of implementation. It provides supervision and implementation of the academic calendar prepared by the Ronaki Duhok Education Company. Thanks to this action, academic calendars can be produced more effective and educational appropriate in the future. Nonetheless, the main purpose of this practice is to supervise the intramural activities of the school. The contributions and negative aspects for the student and teacher development, whether the activities are done or not and serve the purpose or not are determined through these forms. For example, at Duhok Boys' College, activities are monitored day by day and productivity is improved. At Duhok Girls' College, some activities are forgotten because they are not a ready template for control in ISO Format. In the case of Duhok Boys' College, a form in ISO format was used and the academic calendars were applied and reported so that the students could learn more effectively. At Duhok Girls' College, this type of form was not applied and the possibility of the academic calendar repeating itself constantly was emerged. If this is the case, then the students have also a burden to the opportunity to improve themselves.

\subsubsection{The Follow-up of Agreements and Contracts}

The follow-up of agreements and contracts ensures that agreements and contracts made with any external company are followed. Through the Agreement and the Contract Tracking Form used at Duhok Boys' College, many contracts are automatically renewed when the time comes, and no negative circumstances occur. For example, at the Duhok Boys' College, where contracts with the company providing the technological equipment of the company are followed, all the necessary tools and equipment are provided timely. But at Duhok Girls' College, the fact that contracts have to be extended and the contract conditions are forgotten, which causes problems. In the first week of March, Duhok Girls' College experienced a negative situation. Defective air conditioners have been repaired 3-4 days delayed due to the non-renewal of the contract with the authorized service. This has caused hardships for both staff and trainers as well as students. (See Appendix A-1).

\subsubsection{The Press Follow-Up}

The press follow-up forms are used regularly to present the institution and advertise its works in newspapers or on television. And the follow-up is done in a strict manner. While Duhok Boys' College follow-up the press form as required, the news was forgotten at Duhok Girls' College because it was not implemented and the news were not recorded. (See Appendix A-3)

\subsection{4 "I Have an Idea" Form}

"I have an Idea" form is the most important form that both the staff and the students can use. 


\section{MInstitute Mach $^{m}$}

International Journal of Management Innovation Systems

ISSN 1943-1384

2018, Vol. 3, No. 1

This practice is an extra step that Ronaki Duhok Education Company have begun to implement, rather than a compulsory application of ISO Standards. Thanks to this form, everyone can express ideas to make the institution better. This form, implemented at Duhok Boys' College, effectively contributes to the institution via students. In this way, students can clearly convey their ideas to teachers and administrators and have a say. However, since Duhok Girls' College does not have this form, the staff and students cannot have a say in the school and cannot express their opinions comfortably. This leads to trouble situations in the long run for them. (See Appendix A-4).

\subsubsection{Follow-Up of Incoming Outgoing Documents}

Incoming and outgoing documents from various companies or establishments are followed through Incoming Outgoing Documents form. Through this form applied at Duhok Boys' College, works are arranged and bureaucratic procedures are not tiring. Because the Duhok Girls' College do not use this form, sometimes the documents are lost and this lead to various problems.

\subsubsection{The Follow-Up of School Trips}

The school trip orders and its follow-ups organizes the trips that students will go with the school. The Duhok Boys' College uses the Trip Application Form frequently and everything is kept on record from the teachers' approval to parent's permissions. But Duhok Girls' College experiences hardships because there is no such practice. For example, because the school trip form of a student has disappeared in April, that student could not take part in the trip last minute. Such situations can negatively affect students' motivation. The absence of the trip application form, trip and student permissions and the security problems it created in the starting point of the trip led to return of all students. (See Appendix A-19).

\subsubsection{The Follow-up of Graduated Students}

Thanks to the application of ISO standards, the information of graduated students is recorded and can be used when necessary. While a graduate student at Duhok Boys 'College can quickly access the graduation certificate and diploma, the student at Duhok Girls' College may experience bureaucratic problems and wait a long time to get the documents. The follow-up also ensures that graduates stay in touch with the institution even after graduation. In this respect, an important step is taken in terms of the formation of the institutional identity. (See Appendix A-9).

\subsubsection{Medical Examination Form}

Sometimes the schools have the records of the students who experience some health issues. These records are important and must be archived. For example, a student with a chronic illness at Duhok Boys' College can make necessary interventions on time by the physician in the institution, or may be permitted to go to the doctor without any difficulty. But at Duhok Girls' College this situation is complicated and time consuming. (See Appendix A-13) 


\section{$\Lambda$ Macrothink}

\subsubsection{Test Report}

The test reports keep records of the experiments and the results made in specific courses in the schools. Thus, an analysis can be made about if the tests are reported or not and whether the experiment has been performed. On the other hand, experiments at the request of inspectors are documented through this practice. At Duhok Boys' College, all the experiments that other schools cannot do due to their inadequate laboratories are done in a flawless manner and experience is passed to future years. At Duhok Boys' College this practice is applied and experiments become more useful by improving themselves day by day. However, since this report is not available at Duhok Girls' College, the experiments are skipped and the reports are not recorded. (See Appendix A-5).

\subsubsection{Teacher Lesson Listening}

The class listening system helps to follow how teachers conduct the course and to follow their class and subject dominance. During the year, the teachers are listened 2 times and necessary warnings are made. In this way, teachers are getting better at their work and gain experience. At Duhok Boys' College, by using this form, various analyses are made on how teachers are over time and a solution proposal is presented. In Duhok Girls' College, the disruption of classroom discipline can occur because teachers cannot be followed exactly about how they conduct the lesson. (See Appendix A-2).

\subsubsection{Staff Leave Follow-Up}

The number of leave days of the staff working at the institution is followed up. At Duhok Boys' College, staff obtain the leave days easily. At Duhok Girls' College, this follow-up is not done in detail, which leads to various problems. Through this application, the staff can get the leave days online and the follow-up is also done online. In this respect, leave days are tracked with a certain format template, and problems such as not being able to find the manager and not being able to get the leave on time are eliminated. (See Appendix A-11).

\subsubsection{Expense Claim Form}

If the staff is going to spend for a reason, they fill in a relevant form and forward it to the administrators, and after the approval of the manager, the purchasing manager makes the most suitable purchase. In this way, the expenses can be tracked and made through the institution approval. Thus, unnecessary and excessive expenses are prevented and the budget is balanced. When Duhok Boys' College yearly budget is examined, it is seen that there are no problems while at Duhok Girls' College, the budget is spent 1 month before the end. (See Appendix A-7).

\subsubsection{Material Document Request Form}

With this form that is applied at Duhok Boys' College, all the documents delivered by the General Directorate are recorded. However, at Duhok Girls' College, for example, the photocopy papers that were handed over were disappeared, and the school had to pay for them because there was no delivery report. (See Appendix A-10). 


\section{Macrothink}

\subsubsection{Approved Supplier Form}

2018, Vol. 3, No. 1

At Duhok Boys' College, four different companies were examined when buying food for dining, and prices and quality were recorded with the approved supplier form. In this regard, significant savings have been achieved in the budget. At Duhok Girls' College, different suppliers were worker with since there were no recordings and the possibility of the budget problem was occurred.

\subsubsection{Health Expenses Form}

The health expenses of the staff are covered by Ronaki Duhok Education Company. When the staff makes any health expense, the staff enters it to the system for the approval of the board, and then the accounting makes the necessary payments to the employees. In this respect, at Duhok Boys' College, one does not have to pursue any documents. But at Duhok Girls' College, the payments are overdue and when the bill is lost, the staff also lose the chance to get paid. (See Appendix A-17).

\subsubsection{Travel Allowance Form}

Travels made by the staff related to the institution are recorded through this form at Duhok Boys' College and payments are made after the approval of the board. At Duhok Girls' College, payments cannot be made if the documents are lost and if the expenses are not documented. For example, in March, the staff member who made a business trip did not receive payment for 2 months due to the lack of head office approval. (See Appendix A-6).

\subsubsection{Program Result Form}

The results of the activities are recorded in the program result form. At Duhok Boys' College, the achievements and results of every activity and program are known. In Duhok Girls' College, the results of the programs are not recorded and even the programs can be forgotten.

\subsubsection{Meeting Record Form}

All the records of the meetings held at Duhok Boys' College in the school are entered and saved in the system. These can be followed through the E-School system. All the records are transferred to the necessary staff after the meeting and the staff are alerted and they read what they will do to improve themselves. At Duhok Girls' College, this is not the case. The topics of the meetings are not recorded for later, which also reduces the efficiency. On the other hand, administrative problems arise in terms of functioning and formality.

\subsubsection{Seminar Form}

All seminars attended by staff and teachers are recorded at Duhok Boys' College. At the end of the year, all the students and staff received seminar reports for 1 year. At Duhok Girls' College, even if seminars were held, they were not recorded.

\subsubsection{Parent Visit Form}

All meetings with the parents are recorded at Duhok Boys' College. This documents the efficiency of the student, the prestige of the school and the interest of the parents. Since 


\section{Mll Macrothink}

International Journal of Management Innovation Systems

ISSN 1943-1384

2018, Vol. 3, No. 1

Duhok Girls' College do not keep such a record, for example, parents of a student who did not have good grades blamed the school even they did not attend any school meetings and the school has lost prestige. The school was accused of not warning the parents of a student who has discipline crime although the warning was sent to the parents. As can be seen from these examples, all meetings with parents are required to be recorded. (See Appendix A-16).

\subsubsection{Parent Meeting Record Form}

Through this form applied at the Duhok Boys' College, the wishes and demands of the parents can be transferred to administration quickly. In this way, solutions can be found in a reliable way. At Duhok Girls' College, unfortunately the meetings were not recorded, so the wishes of the parents were forgotten, and even if they were transferred to the director, they were forgotten over time due to lack of attention. This is a major obstacle for the development of the school. (See Appendix A-19).

\subsubsection{Branch Teachers' Meeting}

Branch teachers meet every month at the school. At Duhok Boys' College, these meetings are recorded and everything discussed at the meeting is under the responsibility of the team that attended the meeting, and decisions are implemented quickly after the meetings. Duhok Girls' College is not able to make any progress after the meeting since the meetings are not recorded. The administration, on the other hand, cannot follow up whether these meetings are being held or not. (See Appendix A-20).

\subsubsection{Follow-Up of the Students Leaving the School}

With this application, the reasons of leaving the school can be easily followed. Because Duhok Girls' College do not follow it, the students' problems were not recognized and therefore there was a serious loss of students because they could not solve the problems. In Duhok Boys' College, students were found to have to show "Computer" class as a reason to leave school, so the necessary work was done in this regard and other students in school were prevented from having the same problem.

\subsubsection{Social Media Follow-Up}

Social media is one of the best advertising and promotional tools for the institution and its follow up is an important element. At Duhok Boys' College, this follow-up is done in a strict manner, so social media posts increased to over 200 at the end of the year and the interaction also increased. However, at Duhok Girls' College, the number of shares at the end of the year remains at 58, and there is no significant increase in the number of followers.

\subsection{Questionnaires}

Questionnaires that were asked to the staff, parents and students in the institution (Appendix B 1, 2 and 3) ensure that the institution works in a healthier way. At Duhok Boys' College, this practice is constantly carried out and the level of satisfaction is measured. In the questionnaire that was conducted after the ISO process (Appendix B 1, 2 and 3), questions related to the institution were asked and the overall sum of the questions asked to the teachers, 


\section{Ml Macrothink}

International Journal of Management Innovation Systems

ISSN 1943-1384

2018, Vol. 3, No. 1

parents and students was $92.86 \%$ for Duhok Boys' College, while for Duhok Girls' this ratio stood at $61.5 \%$ for satisfaction level.

\subsection{Other Applications}

\subsubsection{Regulations}

In addition to the forms, there are other applications within ISO 9001 area. At Duhok Boys' College, the staff knows all their rights, since all the regulations are clear and accessible within the institution. At Duhok Girls' College, there is a chaos because the staff and the managers do not know the rights.

\subsubsection{Directives}

At Duhok Boys' College, all of the directives are ready, for example, because there is an instruction to be held and since the responsible knows what to do directly, there is no problem during an exam. At Duhok Girls' College, there are some inconveniences during the exam because the guidelines are not clear.

\subsubsection{Job Descriptions}

Similarly, job descriptions are clear at Duhok Boys' College and there is no problem, for example, because the Olympics responsible knows his/her job. But there are no definitions in Duhok Girls' Collage and there are confusions regarding authority.

\subsubsection{Certificates}

At Duhok Boys' College, all of the certifications are under registration, so one can check which staff has which certificate at any time. Duhok Girls' College does not have such opportunity. Likewise, certificates are also important for students. At Duhok Boys' College, when students claim a certificate, it is checked and quickly approved. In Duhok Girls' College, however, the certificate of four students in June was not accepted because they were not in the system and the students lost confidence to the school.

\subsubsection{Agreements}

Again, all contracts made with Duhok Boys' College are recorded and therefore there are no problems. At Duhok Girls' College, the air conditioning problem that we mentioned had before was experienced.

\subsubsection{Administration Schema}

The administration schema is definite at Boys' College. The job descriptions and authorities of the relevant persons in all management units are specified under the quality standard. However, at Duhok Girls' College, the job descriptions and authorities of the relevant departments are not clearly defined, and administrative difficulties occurred during the year.

\subsubsection{Quality Objectives}

At Duhok Boys' College, all quality objectives have been identified. The commitment to the goals set at the beginning of the year, has been checked at the end of the year and the 


\section{Macrothink}

International Journal of Management Innovation Systems

ISSN 1943-1384

2018, Vol. 3, No. 1

necessary measures have been taken for the following year. In Duhok Girls' College, as the targets are not determined, the institution repeats itself and cannot develop. Due to the irregularly recorded work, there can be no positive or negative retrospective evaluation and that is a big factor for development.

\subsubsection{Business Plans}

Because business plans are created at Duhok Boys' College, daily, weekly, monthly and yearly jobs are certain and administrative staff and teachers do not forget what they will do. In Duhok Girls' College, since there is no regular and certain follow-up system, forgetting is happening and things are hindering.

\section{Results and Discussion}

Under Ronaki Duhok Education Company, Duhok Boys' College is one of the leading educational institutions implementing the ISO 9001 quality management system at the highest quality. Duhok Boys' College is able to control itself at the end of the year by setting its quality objectives in accordance with ISO 9001: 2015. This provides a better quality and reliable service to both the staff and the students.

Thanks to ISO 9001 standards, Duhok Boys' College is an educational institution that achieves the followings:

- In case of adverse situation that may arise in educational institutions, the risks are analyzed. Preparations can also be made according to these risks.

- The school's profile is prepared.

- Annual planning is done. In this way, students are provided with better quality education.

- Job descriptions are defined.

- Regulations are prepared in an appropriate manner.

Duhok Girls' College does not increase the prestige of the school by not implementing these standards, also it does not open the way for the students to be more active and successful in their education life. According to the study result, every education institution should support itself with ISO standards. Because Duhok Girls' College does not use these standards, it experiences the following:

- Their images are not getting stronger

- Customer satisfaction is not provided

- Target audience and number of customers do not increase

- Competitiveness that is valid in all sectors does not increase

- Not being effective in management

- The shortcomings are not resolved in time 


\section{$\triangle$ Macrothink}

International Journal of Management Innovation Systems

ISSN 1943-1384

2018, Vol. 3, No. 1

\section{Conclusion}

When we look at all these reviews and comparative results, we can see striking conclusions. Despite the fact that Duhok Boys' College's performances are disciplined and organized in a regular and archived manner, there has been chaos and indiscipline at the Duhok Girls' College because there are no Regulations, Directives, Job Descriptions, Agreements, Administrative Schema, Quality Objectives, Business Plans and most importantly Fixed Forms. Especially at Duhok Girls' College, because of the many different forms used, it has caused convenience problems. At the end of the year Duhok Boys' College experienced a loss of 2.3 percent of the current student, while Duhok Girls' College suffered a loss of 14.1 percent due to the lack of ISO 9001 applications. Thus, Duhok Girls' College took place in written and visual media only 2 times a year, while Duhok Boys' College frequently found itself in the written and visual media. At the end of the year, the satisfaction rate of the students in the institution was 93.2 percent in Duhok Boys' College and 62.5 percent in Duhok Girls' College.

The ISO 9001 Certificate provides maximum benefits to educational institutions. The ISO 9001: 2015 Quality Management Systems adopted by the Institutions aims at retrospective archiving, more regular and clear understanding of the operation performed. ISO 9001 standards will help employees and increase the level of customer satisfaction by adopting an approach that begins to apply more efficient work systems and focuses on the organization's business goals.

Table 1. The questionnaire results conducted after ISO / a. Questionnaire results

\begin{tabular}{|l|c|c|}
\hline Questionnaire Results & Duhok Boys' College & Duhok Girls' College \\
\hline Student Satisfactions & $\% 93,2$ & $\% 62,5$ \\
\hline Parent Satisfactions & $\% 94,3$ & $\% 65,1$ \\
\hline Staff Satisfactions & $\% 91,1$ & $\% 56,9$ \\
\hline General Average & $\% 92,8$ & $\% 61,5$ \\
\hline
\end{tabular}

Table 2. The comparison table and results of the studies after ISO 9001/b. Year-End organization evaluation (See Appendix B -2)

\begin{tabular}{|l|c|c|}
\hline Evaluation Results & Duhok Boys' College & Duhok Girls' College \\
\hline $\begin{array}{l}\text { The ratio of dis-enrolled students to whole } \\
\text { students }\end{array}$ & $\% 2,3$ & $\% 14,1$ \\
\hline The number of media coverage & 21,6 & 2,4 \\
\hline The ratio of new students to whole students & $\% 7,4$ & $\% 1,1$ \\
\hline The ratio of spending budget & $\% 96,4$ & $\%$ \\
\hline
\end{tabular}




\begin{tabular}{|c|c|c|}
\hline $\begin{array}{l}\text { The ratio of event realization in academic } \\
\text { calendar }\end{array}$ & $\% 93,1$ & $\% 75,6$ \\
\hline $\begin{array}{l}\text { The ratio of test realization from the annual } \\
\text { plan }\end{array}$ & $\% 87,8$ & $\% 54,5$ \\
\hline Study trip numbers organized for students & 8 & 2 \\
\hline $\begin{array}{l}\text { Conference-Seminar number organized for } \\
\text { students, staff and parents }\end{array}$ & 5 & 1 \\
\hline $\begin{array}{l}\text { The ratio of teachers whose class was } \\
\text { listened and whole teachers }\end{array}$ & $\% 100$ & $\% 78,4$ \\
\hline The ratio of completed meeting reports & $\% 100$ & $\% 35,1$ \\
\hline The ratio of staff acting according to shifts & $\% 83,4$ & $\% 76,3$ \\
\hline $\begin{array}{l}\text { The ratio of reporting the program result } \\
\text { forms }\end{array}$ & $\% 95,4$ & $\% 0$ \\
\hline The reporting of health expenses & $\% 87,5$ & $\% 23,6$ \\
\hline $\begin{array}{l}\text { The ratio of sharing the in-house activities on } \\
\text { social media }\end{array}$ & $\% 97,9$ & $\% 15,3$ \\
\hline The ratio of reporting the branch meetings & $\% 100$ & $\% 15,2$ \\
\hline
\end{tabular}

\section{References}

Aytaç Acardağ. (2008). Çalışma Yaşamında İş Sözleşmesinin Önemi. Lüleburgaz Hürfikir.

Benefits of ISO. http://www.iso9001.com/benefitsofiso9001.asp Date of access: 04 July 2018 https://www.muhasebenet.net/makale_aytac\%20acardag_calisma\%20yasaminda\%20is\%20so zlesmesinin\%20onemi.doc

What are the benefits of ISO 9001 standards? http://www.standartkalite.com/iso9001_faydalari.htm, Date of access: 15 July 2018

What is ISO 9001? http://belgelendirme.ctr.com.tr/iso-9001-nedir.html Date of access: 04 July 2018 
MI Macrothink

Appendix 1. B-1
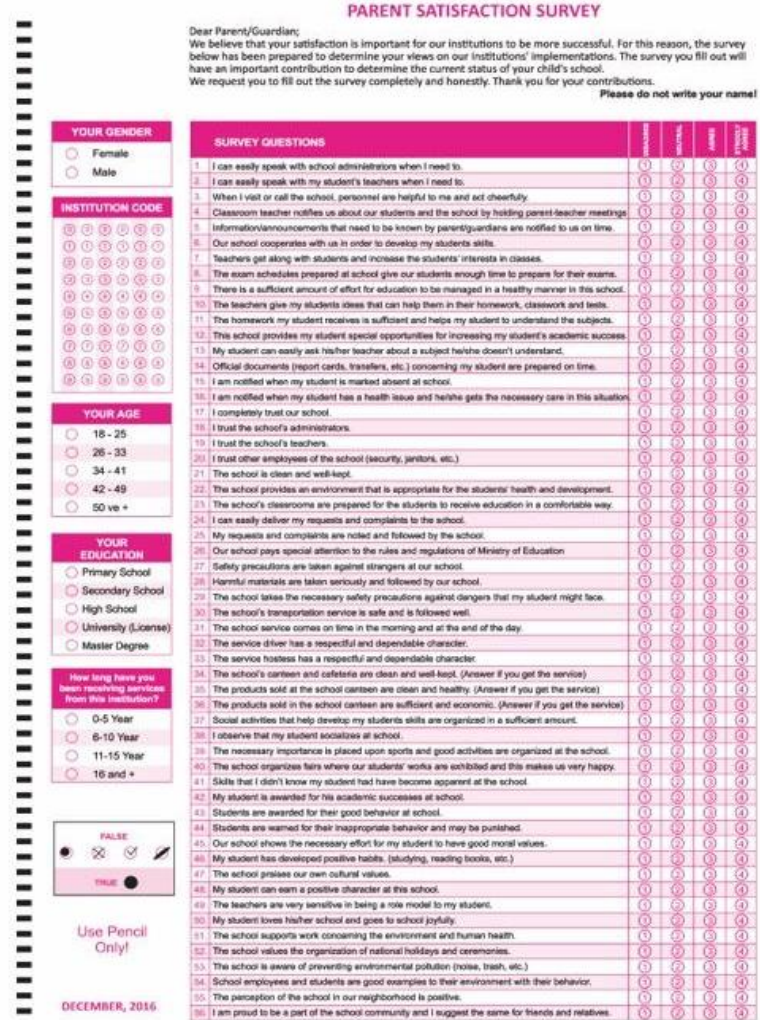

Appendix 3. B-3

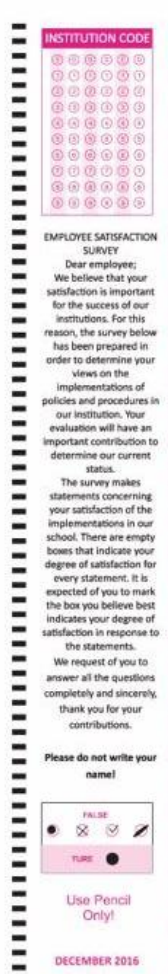

EMPLOYEE SATISFACTION SURVEY

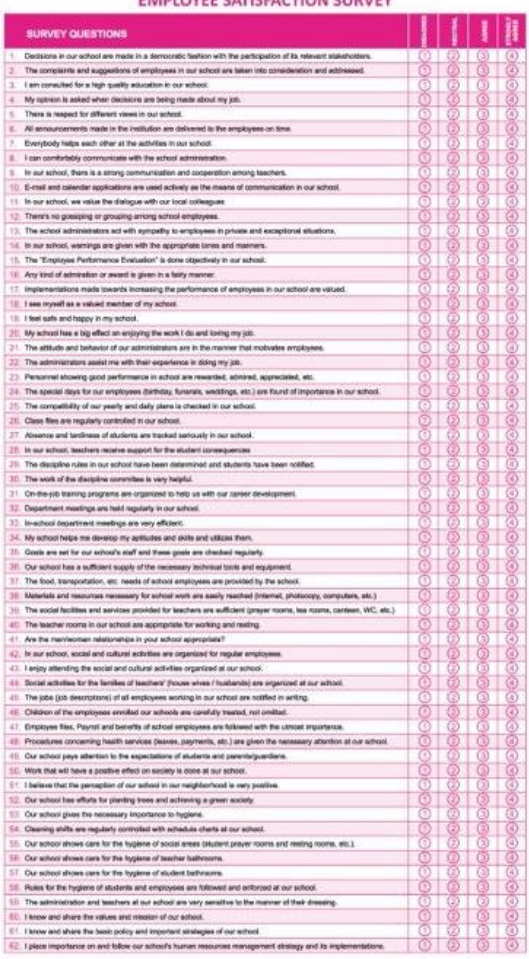

International Journal of Management Innovation Systems

ISSN 1943-1384

2018, Vol. 3, No. 1
Appendix2. B-2

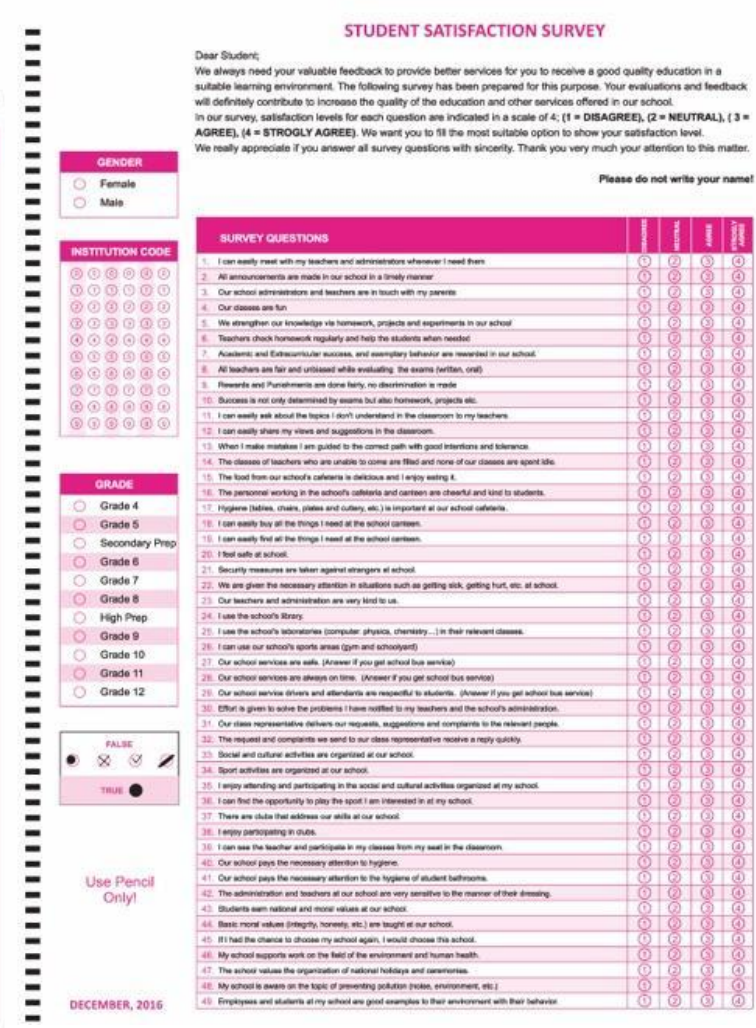

Appendix 4. C-1

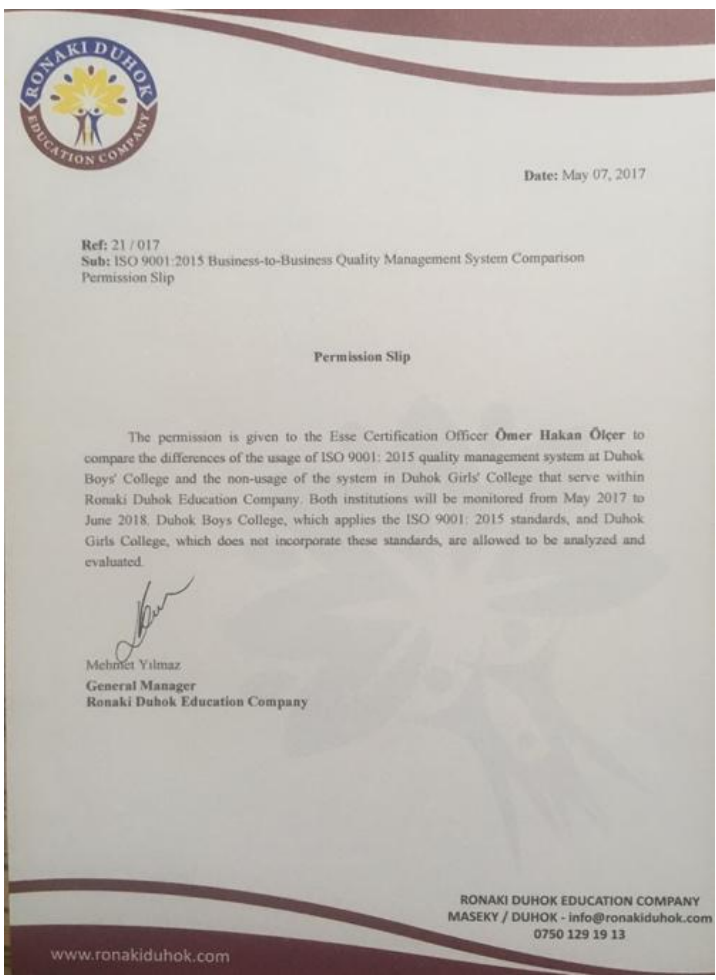




\section{Ml Macrothink Mnstitute ${ }^{\mathrm{I}}$}

\section{Appendix 5. C-2}

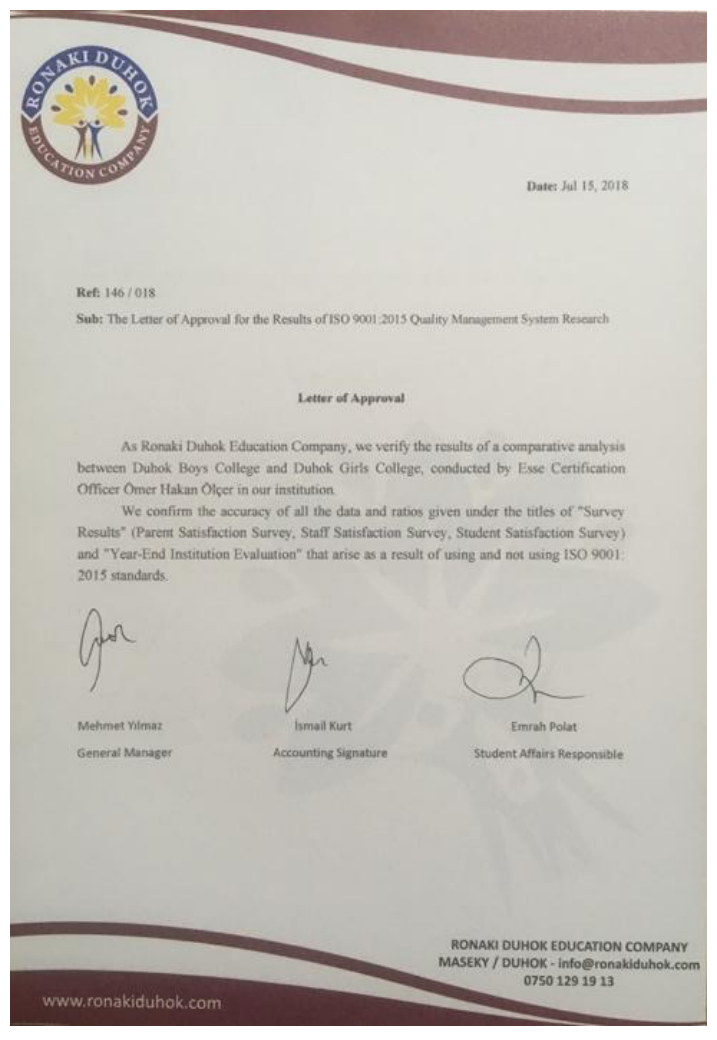

\section{Appendix 7. A-2}

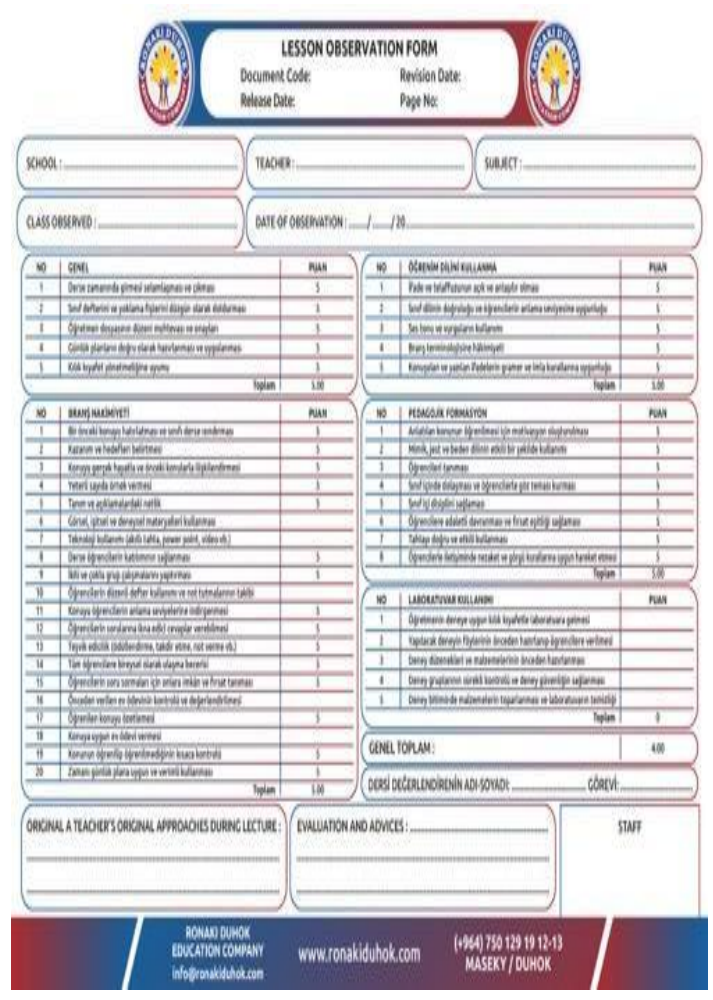

International Journal of Management Innovation Systems

ISSN 1943-1384

2018, Vol. 3, No. 1

\section{Appendix 6. A-1}

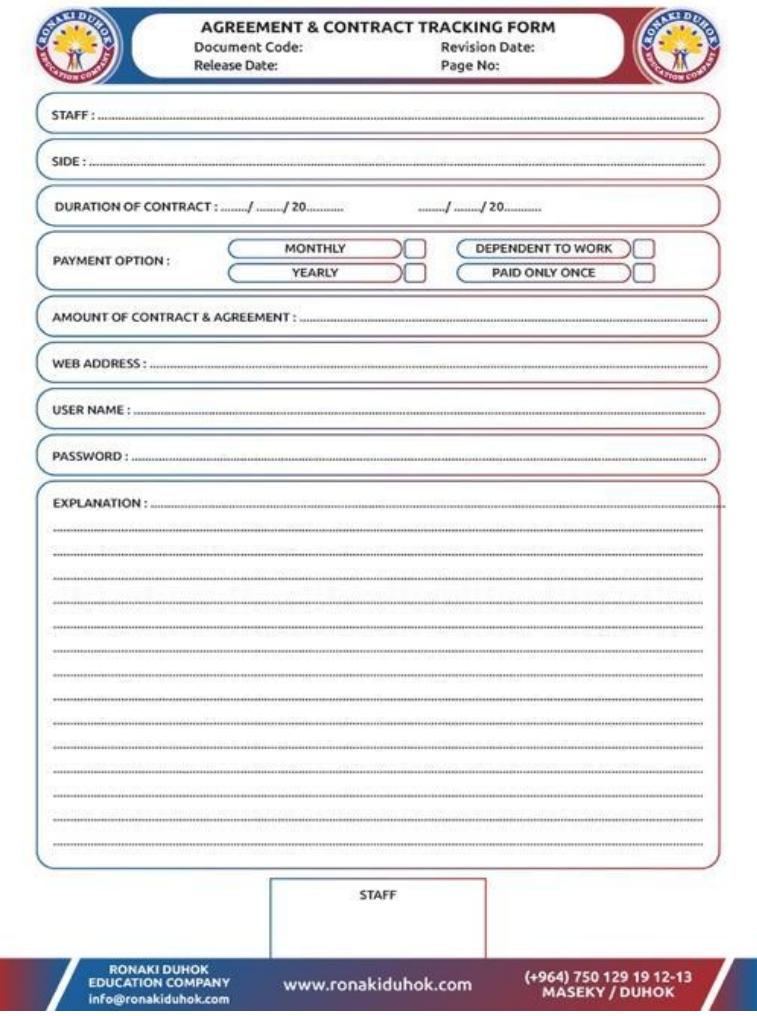

Appendix 8. A-3

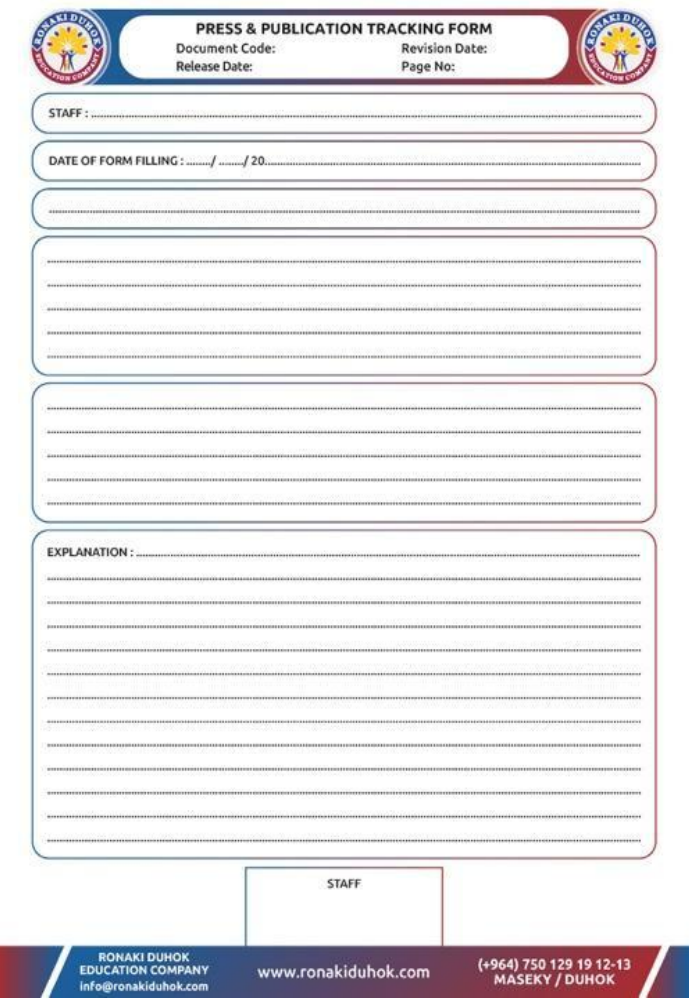




\section{MlMacrothink}

Appendix 9. A-4

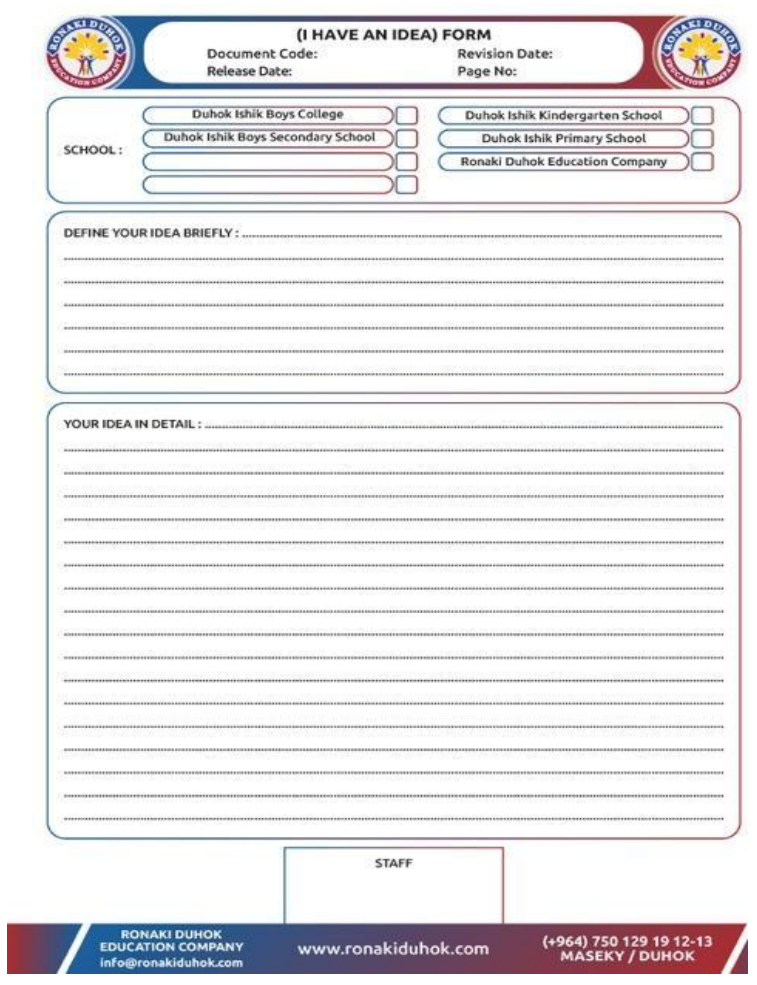

Appendix 11. A-6

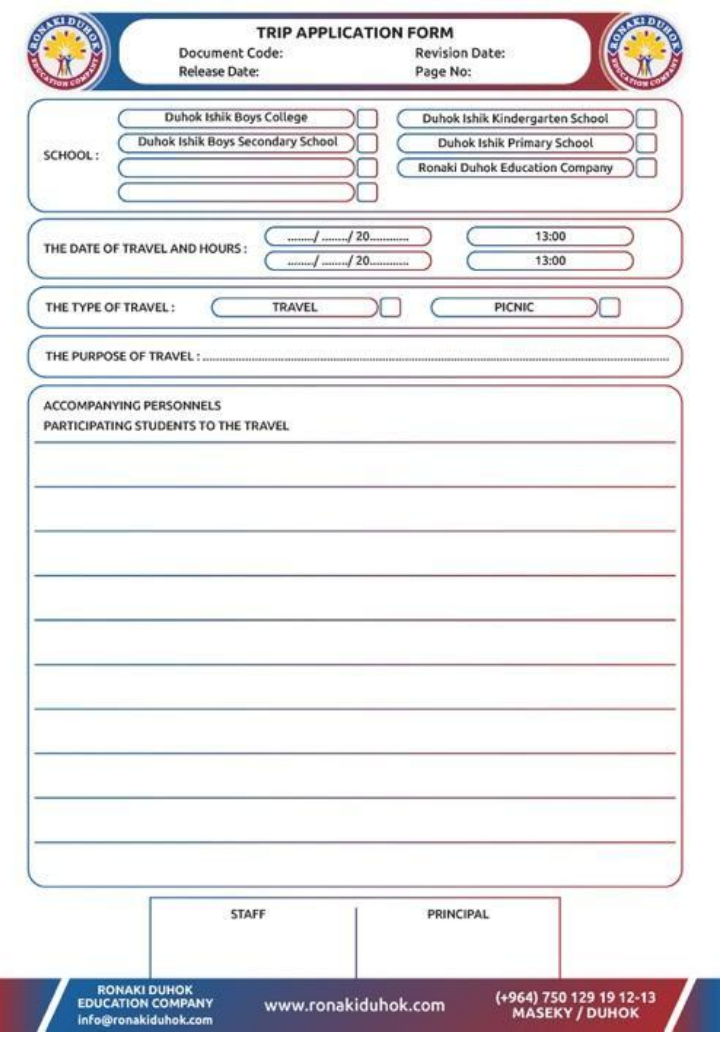

International Journal of Management Innovation Systems

ISSN 1943-1384

\section{Appendix 10. A-5}

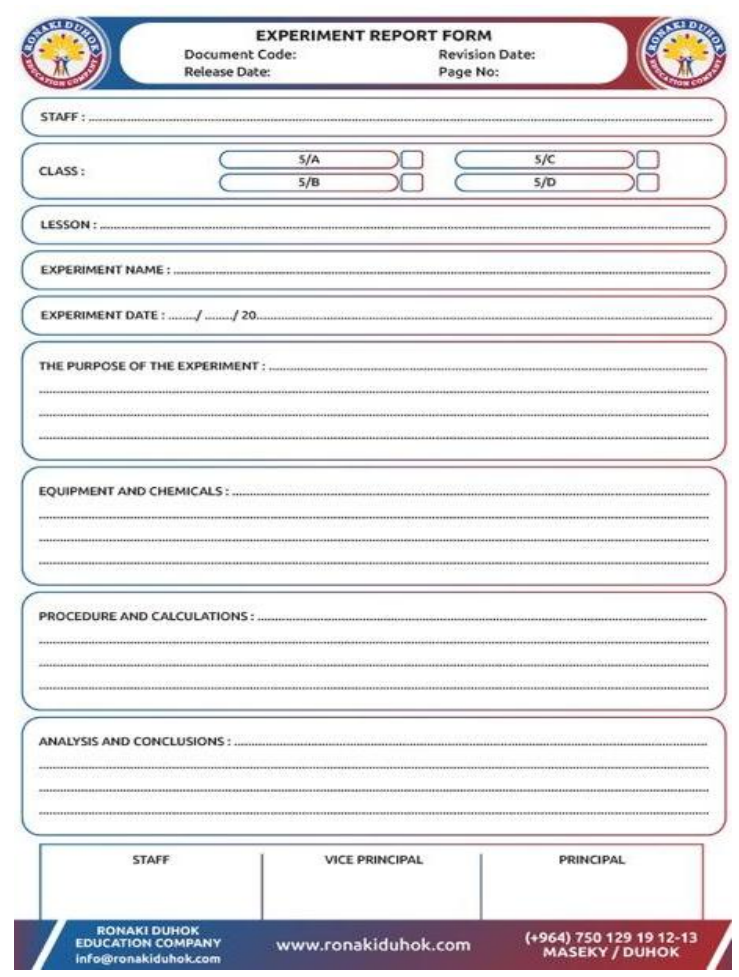

Appendix 12. A-7

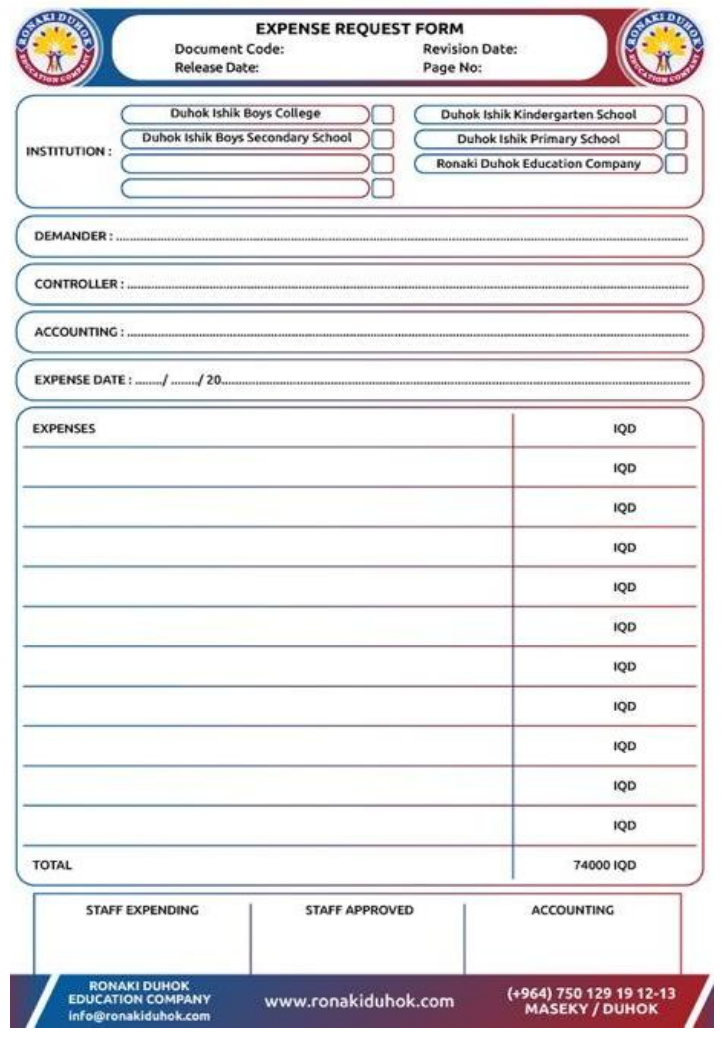




\section{Macrothink} Appendix 13. A-8

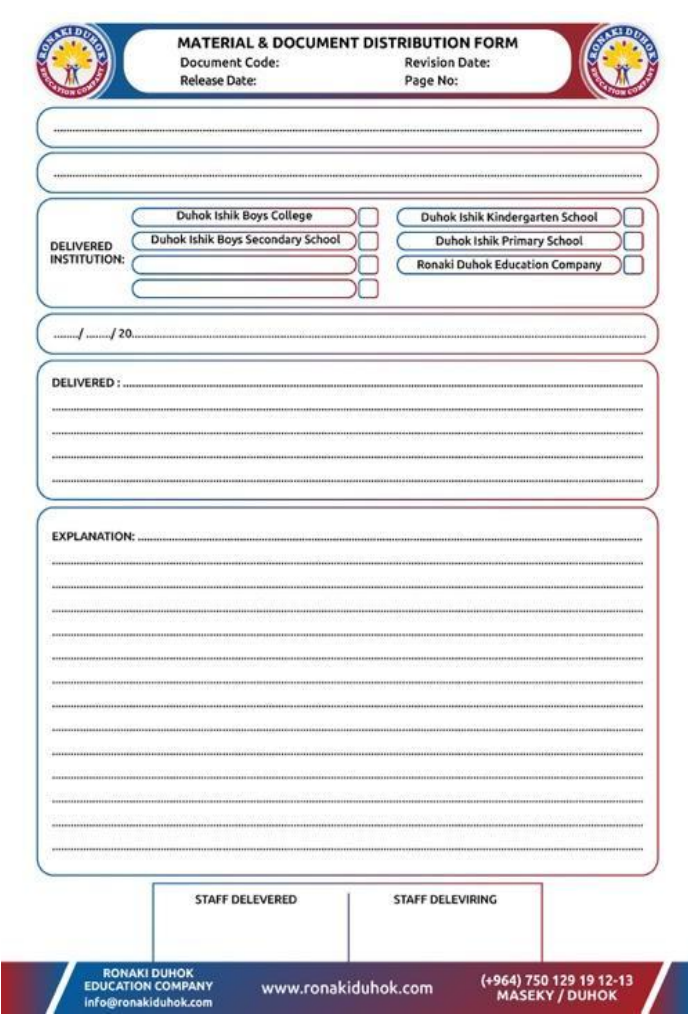

\section{Appendix 15. A-10}

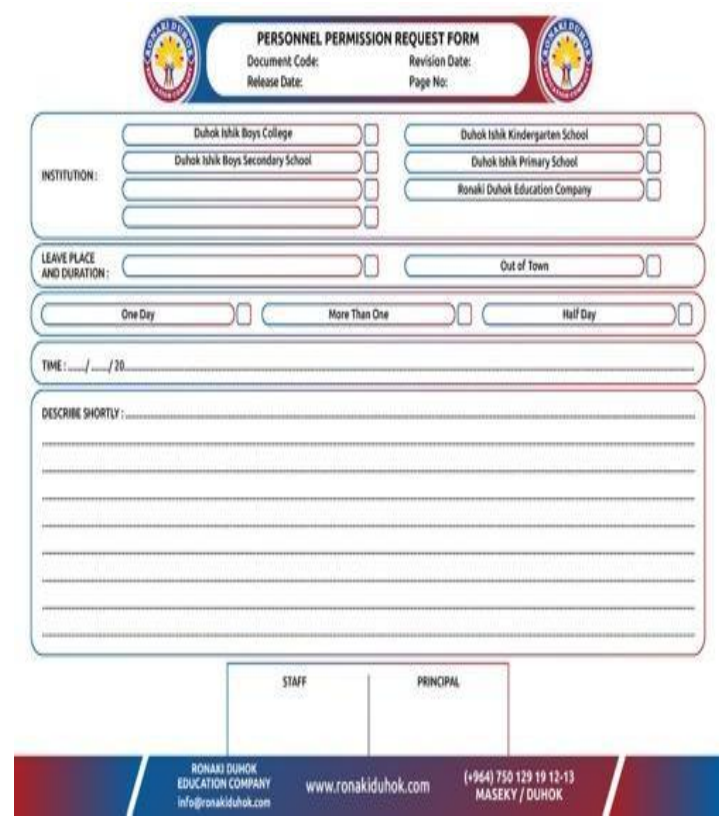

International Journal of Management Innovation Systems ISSN 1943-1384 2018, Vol. 3, No. 1

\section{Appendix 14. A-9}
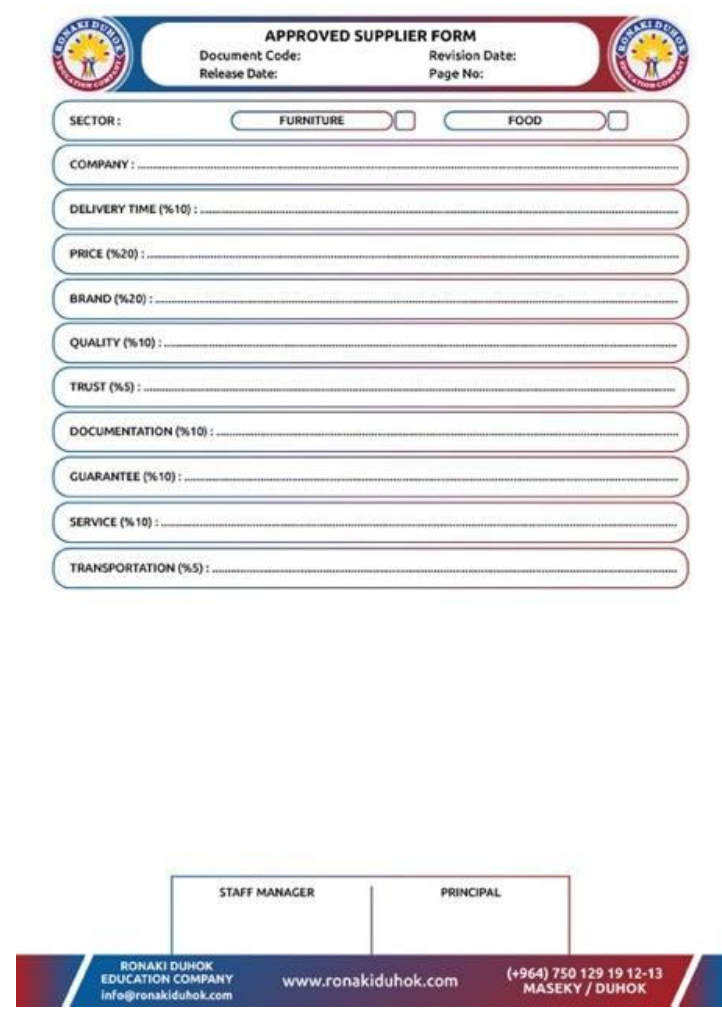

\section{Appendix 16. A-11}

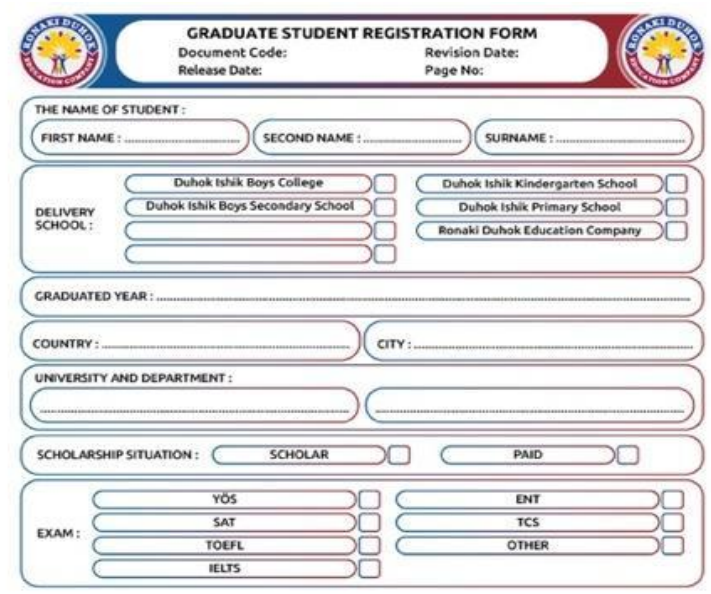

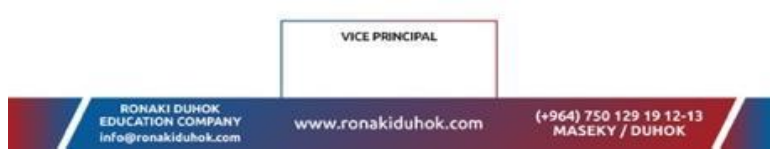


Appendix 17. A-12

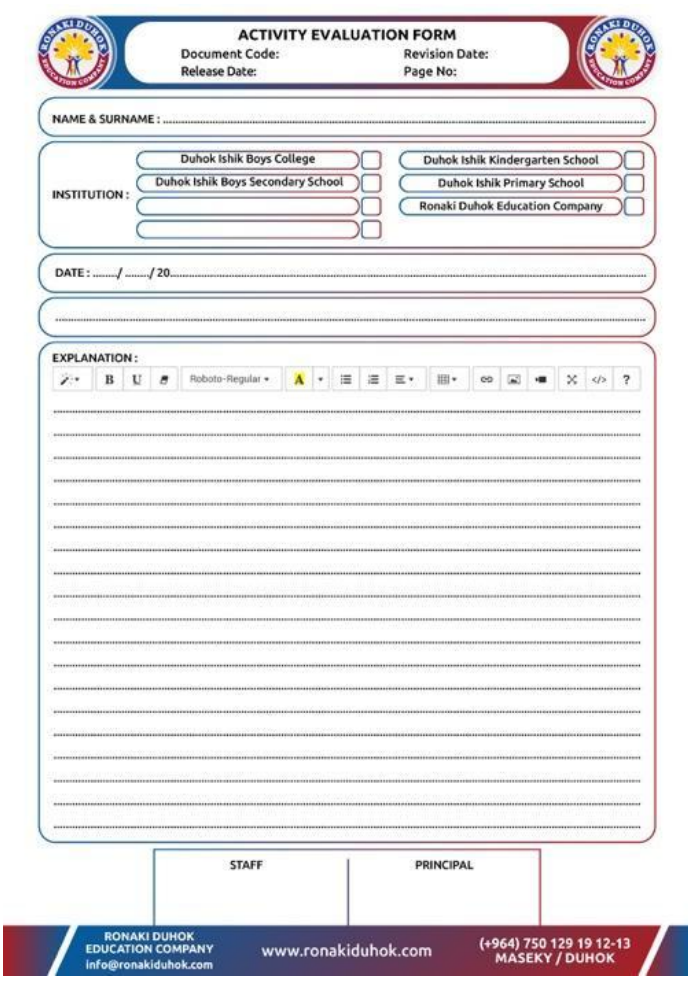

\section{Appendix 19. A-14}

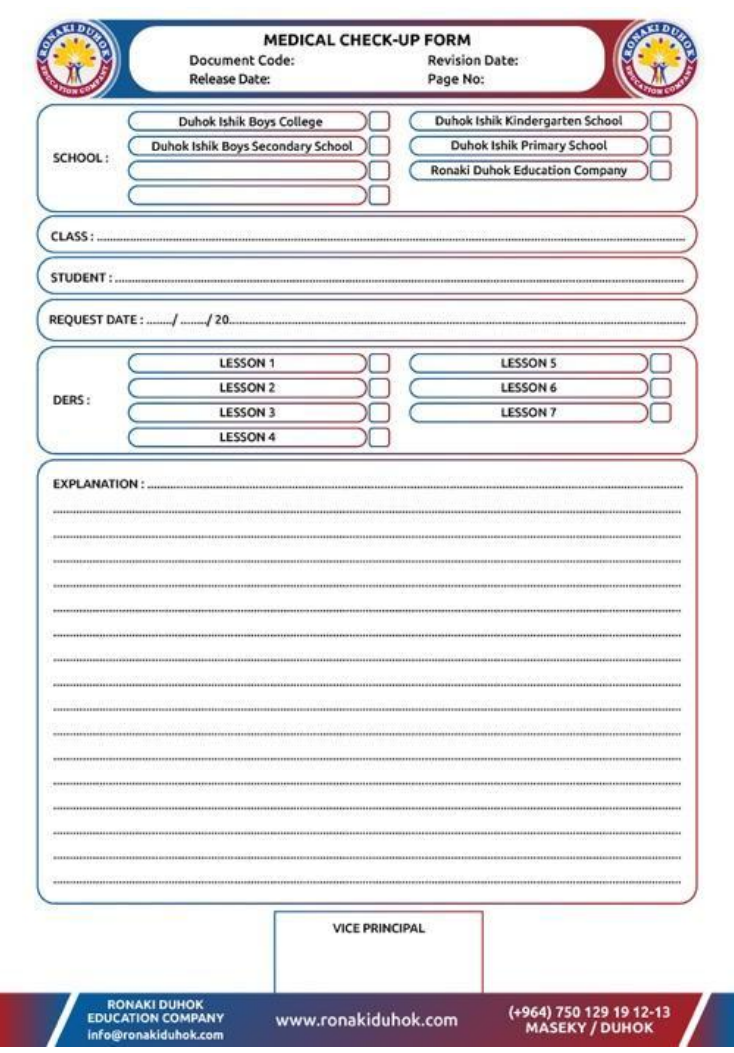

Appendix 18. A-13

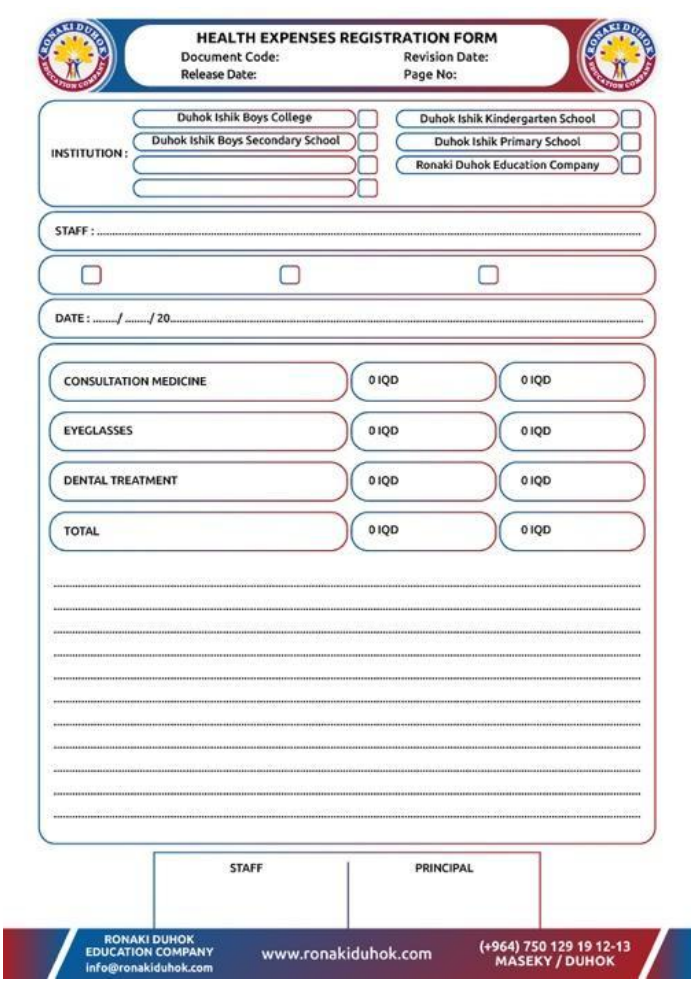

Appendix 20. A-15

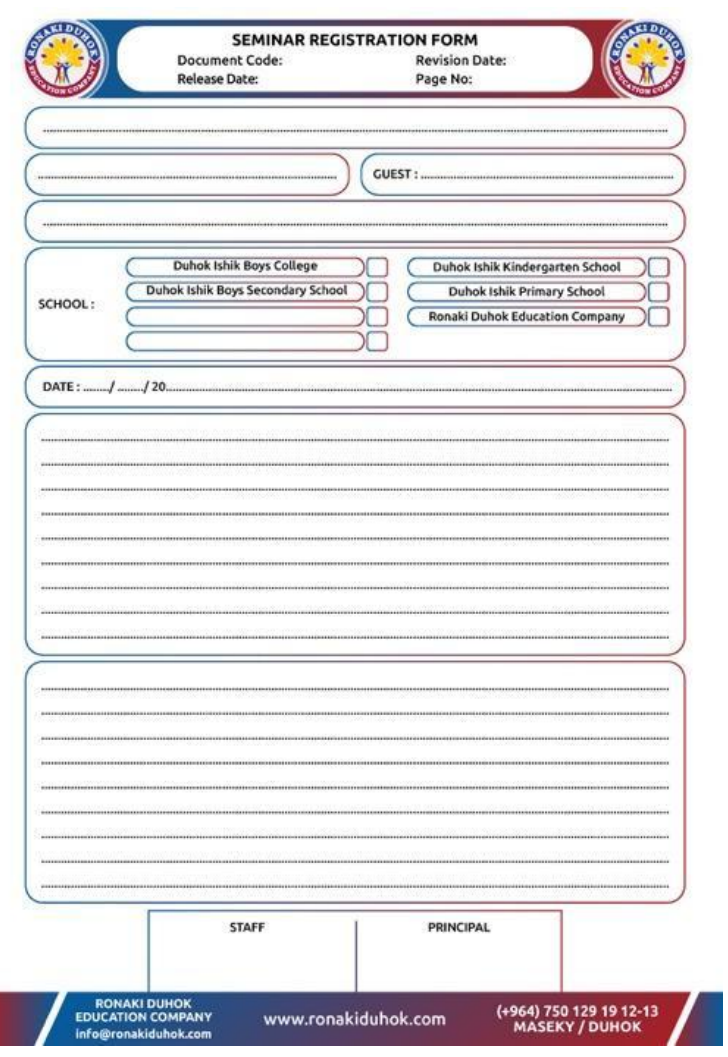


Appendix 21. A-16

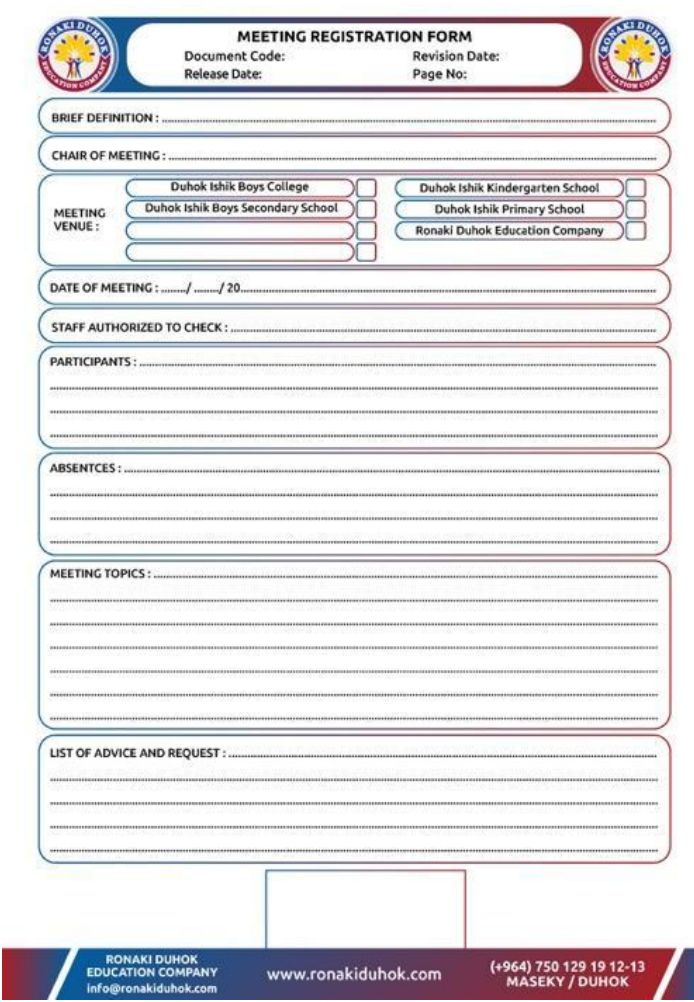

\section{Appendix 23. A-18}

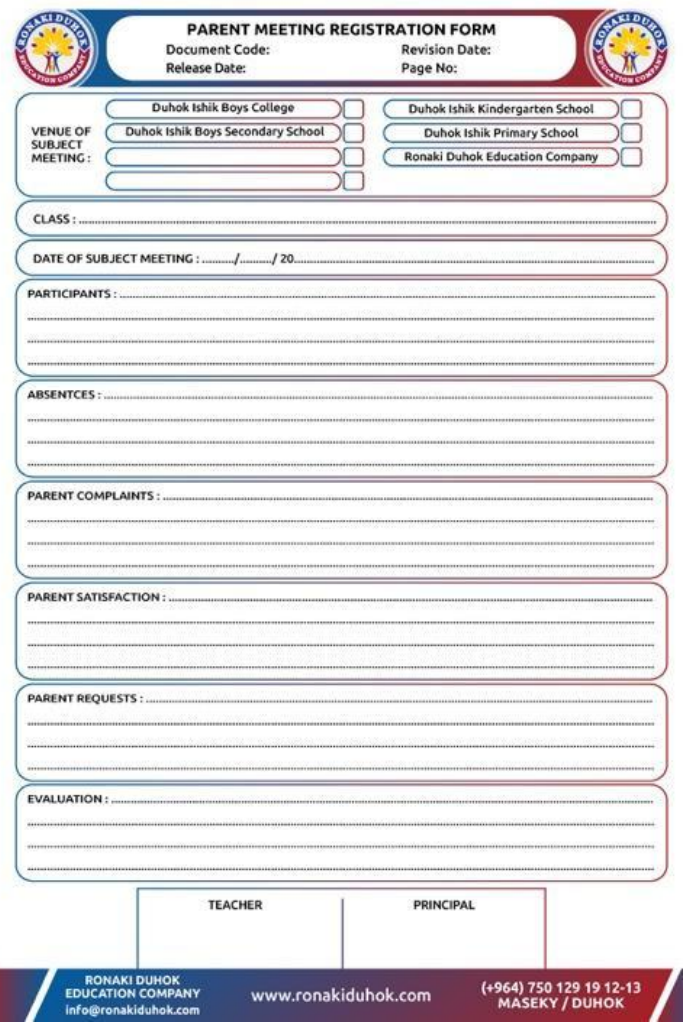

Appendix 22. A-17

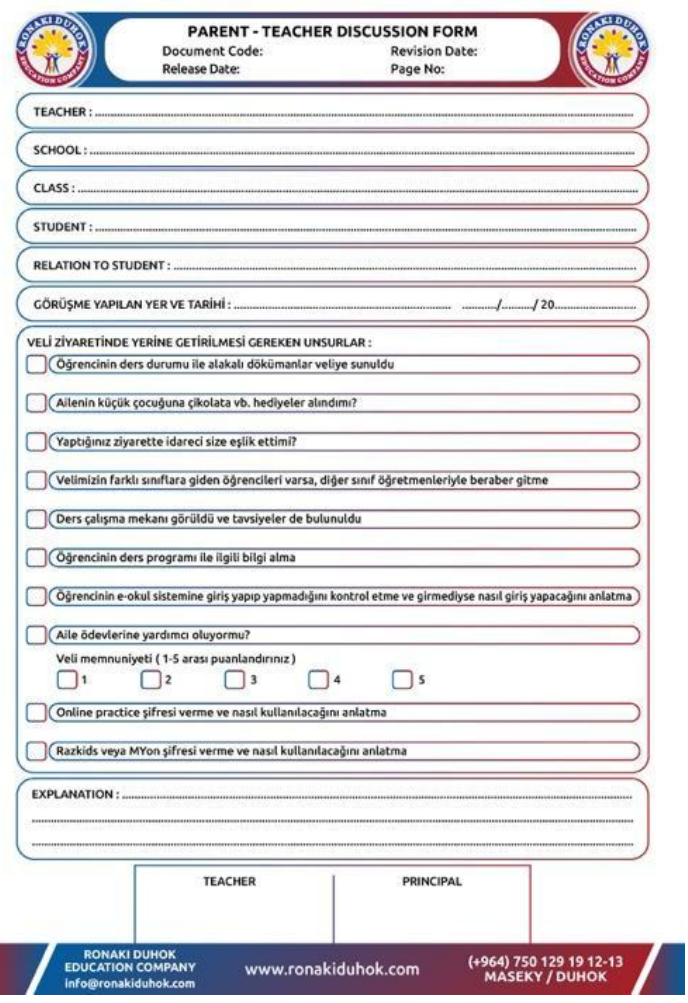

Appendix 24. A-19
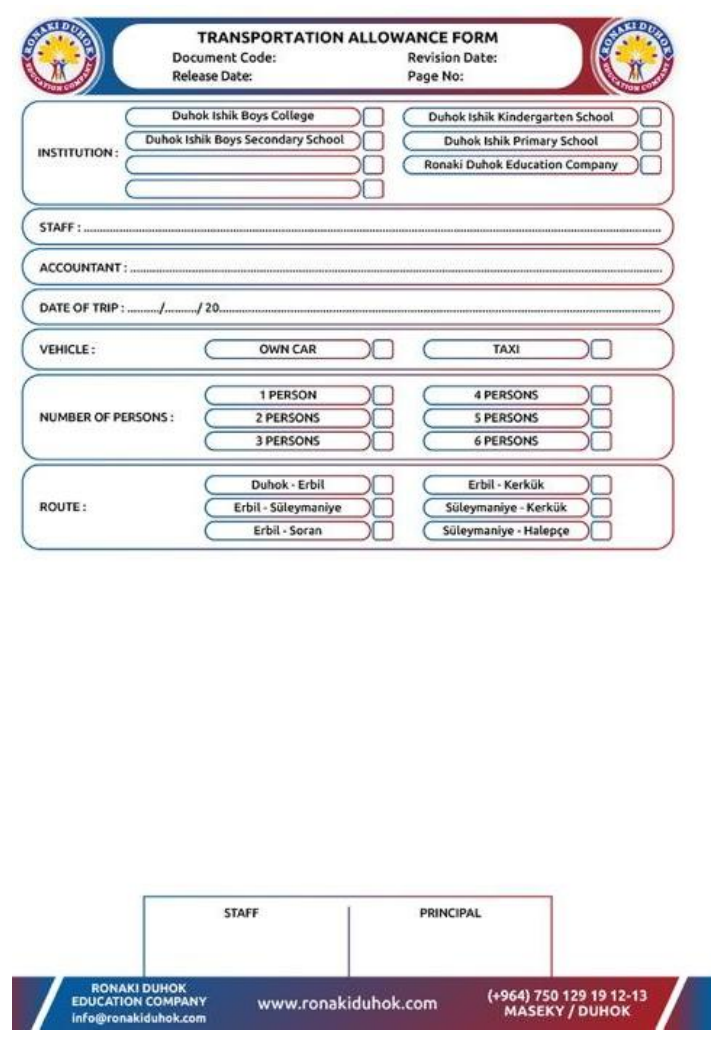


\section{Appendix 25. A-20}

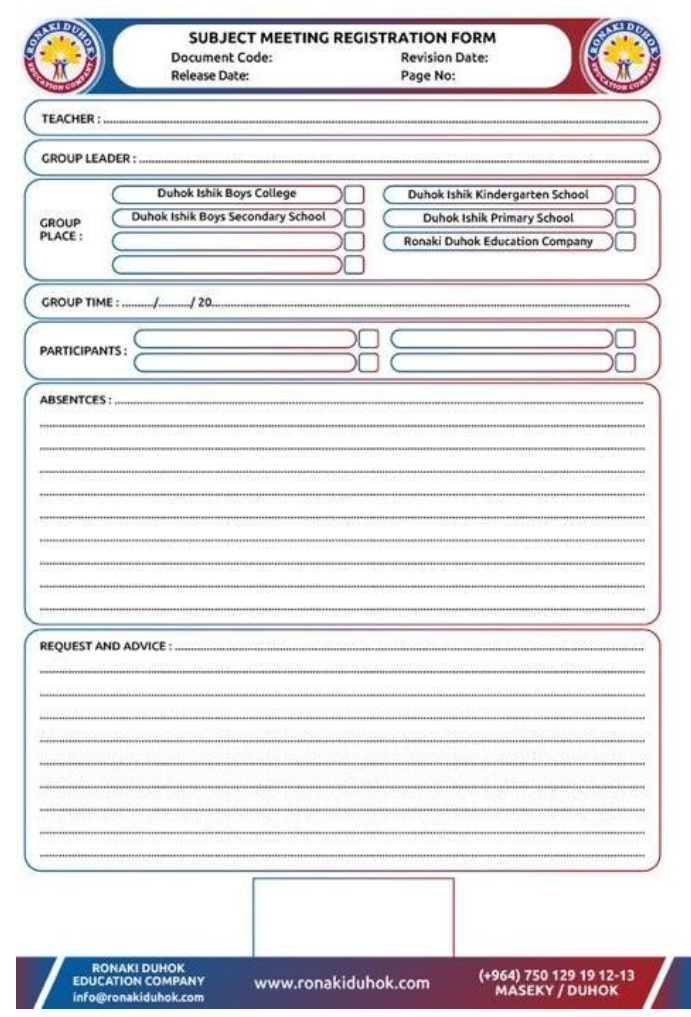

\section{Copyright Disclaimer}

Copyright for this article is retained by the author(s), with first publication rights granted to the journal.

This is an open-access article distributed under the terms and conditions of the Creative Commons Attribution license (http://creativecommons.org/licenses/by/3.0/). 